\title{
CONSERVAÇÃO: MAIS ÉTICA DO QUE ECONOMIA
}

\author{
Conservation: More Ethic Then Economy
}

Sylvio Péllico Netto ${ }^{1}$

Saulo Henrique Weber ${ }^{2}$

As discussões sobre a conservação da natureza vêm tornando-se cada vez mais freqüentes e intensas, uma vez que é por meio dela que a vida, como a conhecemos, continuará sendo possível. Esse assunto tem sido amplamente discutido em congressos e encontros em nível regional e mundial por professores, pesquisadores e profissionais dessa área, bem como por pessoas interessadas na manutenção do patrimônio genético-ambiental dos ecossistemas que compõem nosso planeta. É importante salientar que as decisões tomadas em congressos técnico-científicos influenciam de forma significativa a vida cotidiana das pessoas.

Apesar de ser evidente que pesquisas sobre os ecossistemas devem ser permanentemente realizadas, uma maior conscientização deve ser exercida para que o conhecimento sobre eles seja ampliado. É necessário enaltecer a premissa de que não há vida sem meio ambiente e que esse deve ser tratado com respeito e ética.

Muitos autores sempre questionaram se o tema conservação da natureza deveria ser considerado como um campo do conhecimento e ser ensinado como um programa de aprendizagem no currículo escolar, entretanto, um grande número de estudiosos do assunto considera que conservação da natureza deve ser compreendida como uma parte intrínseca da vida, um estado de espírito, que deve compor todo o processo educacional do homem.

Leopoldo, da Universidade de Wisconsin, definiu conservação como a aceitação e manutenção de "um estado de harmonia entre o homem e a terra". Essa é essencialmente a idéia de conservação, é a meta que o homem, no interesse mais amplo de sobrevivência, não pode deixar de perseguir. Dessa forma, esse é o destino que a sociedade pode alcançar se ocorrer uma forte adesão de pessoas, cujas convicções se alastram e se fixam de maneira permanente.

Para Leopoldo, o conceito de conservação deve estar impregnado no comportamento moral, ético e religioso de todos os homens. Ele afirma que:

Toda a ética até agora evoluída se fundamenta em uma única premissa: que o indivíduo é um membro de uma comunidade de partes interdependentes. Seu instinto o prepara para competir pelo seu espaço naquela comunidade, mas sua ética o prepara também para cooperar, talvez porque exista um real espaço para competir.

1 Eng. Florestal, Dr. Prof. Titular da PUCPR, Rua Rocha Pombo, 791, CEP 80530-290, Juvevê, Curitiba, PR, pellico.sylvio@pucpr.br.

2 Matemático, M.Sc, Rua Fátima Bark, 405, CEP 81130-270, Capão Raso, Curitiba, PR, sauloweber@gmail.com. 
Ele ainda observou que:

Conservação não é atingida se a política não assume o correto conceito de terra. O homem abusa da terra porque ele a imagina como uma commodity que lhe pertence. Quando se aceita a terra como uma comunidade da qual se pertence, talvez se possa então usá-la com amor e respeito. Não existe outra maneira para que a terra sobreviva aos impactos do bomem mecanizado....

Weaver, da Universidade de Ohio, afirma que mesmo após quase um século de propaganda, a conservação continua ainda a passos lentos. A usual resposta para essa situação é "mais educação sobre conservação". É realmente verdade que somente o aumento de educação resolve? Está faltando algo para complementar a educação? É difícil formalizar tal contexto, pois, ao final, o que se sumariza é:

Obedeça a lei, vote corretamente, torne-se sócio de um organização ambiental e pratique o que se entende por conservação em sua terra; o governo fará o resto.

Tal atitude comodista parece ser o que se encontra na maioria das sociedades modernas, inclusive no Brasil. A consciência e o exercício dela para com o meio ambiente geralmente só foram atingidos no mundo a partir da educação, razão pela qual será importante que a educação ambiental seja intensamente praticada em todas as escolas e em todos os níveis de formação.

Esta não é uma forma muito fácil para se conseguir algo que valha a pena? Não define o que é certo, nem o que é errado, não atribui obrigações, não pede sacrifício algum e não implica em mudanças na filosofia de valores. Relativo ao uso da terra somente se pede culto ao interesse pessoal. Até quando esse tipo de educação vai perdurar?
O processo educacional é lento e não encoraja otimismo. As ações conservacionistas geralmente são tímidas, iniciam com entusiasmo e com expectativa de rápido sucesso, e pressupõe que as pessoas se envolvam e assimilem a magnitude de suas obrigações. Tais obrigações não têm sentido sem consciência. O problema neste contexto é enfrentar o quanto existe de real consciência social no povo sobre a terra.

Nenhuma importante conquista poderá ser conseguida em ética sem uma mudança interna na lealdade, nas afeições, nas convicções e em outras características virtuosas da intelectualidade. Conservação ainda não permeou, expressivamente, tais fundamentos da conduta humana.

Para que haja avanços nas ações de conservação é preciso que questões éticas sejam debatidas desde os primeiros anos da educação básica. É importante considerar que, se considerássemos apenas os fatores econômicos, todos os recursos ambientais disponíveis seriam utilizados e rapidamente tornar-se-ia impossível a vida neste planeta.

A questão ética está implícita na questão econômica. Para que haja um crescimento permanente, no qual as pessoas tenham qualidade de vida e possam produzir cada vez mais, é imprescindível que exista um acordo silencioso, mútuo e permanente entre as partes que integram o sistema. Se houver um desequilíbrio neste conjunto de ações, a economia entrará em colapso e ambos terão perdas significativas.

Conclusivamente, conservação é mais ética e menos economia. Ou ainda, a questão da conservação deve ser tratada preteritamente considerando-se que a ética não deve ser subalterna aos avanços econômicos.

A formação do homem nas questões ambientais deve acompanhá-lo desde a educação familiar até a sua maturidade, com especial destaque aos conceitos de conservação e, principalmente ética, sobre o uso e manipulação dos recursos naturais. 